\title{
Respon Mahasiswa pada Pembelajaran Hybrid Pasca Pandemi Covid-19
}

\author{
Denni Ismunandar ${ }^{1}$, Nandang² \\ Program Studi Pendidikan Matematika ${ }^{1,2}$ \\ Universitas Wiralodra ${ }^{1,2}$ \\ Email: denni.ismunandar@unwir.ac.id ${ }^{1}$, nandang@unwir.ac.id ${ }^{2}$
}

\begin{abstract}
Abstrak. Kasus Corona di Indonesia pada bulan Juni 2020 sudah mulai melandai. Hal ini berdampak pada kebijakan perguruan tinggi. Dampak tersebut adalah pembelajaran dilaksanakan secara hybrid, dengan mematuhi protokol kesehatan. Oleh karena itu, peneliti melakukan penelitian ini dengan tujuan mengetahui respon mahasiswa pada pembelajaran secara hybrid. Metode kualitatif digunakan untuk mendeskripsikan data yang diperoleh. Data dikumpulkan melalui angket yang diberikan kepada mahasiswa peserta mata kuliah Statistik Matematik Teori Peluang dengan partisipan sebanyak 11 orang mahasiswa. Data yang diperoleh selanjutnya diproses menggunakan Atlas.ti. Hasil penelitian ini yaitu: (1) Pada saat mengajar dosen mengirimkan materi berupa file dan foto, selanjutnya dibahas menggunakan WhatsApp melalui Voice Note atau menggunakan Zoom; (2) Metode yang digunakan dosen kurang membantu dalam mengembangkan kemampuan bernalar mahasiswa; (3) Mahasiswa menginginkan pembelajaran luring, pembelajaraan menggunakan Google Classroom, Diskusi, dan lain - lain untuk membantu mahasiswa memahami materi perkuliahan; (4) Menurut mahasiswa, strategi yang dapat meningkatkan kemampuan menalar mahasiswa adalah pembelajaran secara luring, pemberian contoh yang lebih banyak, colaboratiflearning, dan lain lain; (5) Saran mahasiswa untuk dosen yaitu dalam mengajar tidak terburuburu atau terlalu cepat, menggunakan maplikasi sehingga menarik mahasiswa untuk belajar, mengganti aplikasi dalam pembelajaran, dan memberikan rekaman setelah selesai mengajar. Berdasarkan hasil penelitian di atas, diharapkan dosen dapat merubah aplikasi, cara mengajar, dan menggunakan aplikasi yang menarik sehingga mahasiswa dapat mengembangkan kemampuan menalar mahasiswa.
\end{abstract}

\section{Kata Kunci: Hybrid learning, WhatsApp, Voice Note, Kualitatif}

\begin{abstract}
Corona cases in Indonesia in June 2021 have started to slope. This has an impact on university policy. The impact is that learning is carried out hybridly, by complying with health protocols. Therefore, researchers conducted this study with the aim of knowing the student's response to hybrid learning. Qualitative methods are used to describe the data obtained. Data was collected through questionnaires given to students participating in the Mathematics Statistics Theory Opportunity course with participants as many as 11 students. The data obtained is then processed using Atlas.ti. The results of this study are: (1) When teaching lecturers to send material in the form of files and photos, then discussed using WhatsApp via Voice Note or using Zoom; (2) The methods used by lecturers are less helpful in developing students' reasoning skills; (3) Students want offline learning, learning using Google Classroom, Discussion, and others to help students understand the subject matter; (4) According to students, strategies that can improve students' reasoning skills are offline learning, giving more examples, colaborative learning, and others; (5) Student advice for lecturers is in teaching not in a hurry or too fast, using maplication so as to attract students to learn, change applications in learning, and provide recordings after completion of teaching. Based on the results of the research above, it is expected that lecturers can change the application, how to teach, and use interesting applications so that students can develop students' reasoning skills.
\end{abstract}

Keywords: Hybrid learning, WhatsApp, Voice Note, Qualitative

\section{A. Pendahuluan}

Bulan Maret 2020 adalah awal mula corona virus disease-19 (Covid-19) masuk ke Indonesia. Virus Corona adalah virus yang menyebabkan epidemi sindrom pernafasan akut (Dryhurst dkk., 2020). Oleh karena itu, kementrian Pendidikan dan Kebudayaan (Kemendikbud) mengeluarkan surat edaran nomor 36962/MPK.A/HK/2020 tentang pembelajaran secara online (Ismunandar dkk., 2021). Namun pada awal bulan Maret 2021 kasus Covid-19 sudah mulai melandai (Pratikto, 2020). Hal ini berdampak pada perubahan tindakan dalam pembelajaran. Salah satu dampaknya adalah perubahan pembelajaran melalui 
online menjadi pembelajaran secara hybrid (Evans dkk., 2018)Hybrid Learning merupakan pembelajaran yang menggabungkan beberapa metode pembelajaran yaitu, pembelajaran yang dilakukan secara ekspositori, pembelajaran yang dilakukan dengan komputer sebagai alat bantu, dan pembelajaran dengan internet (Asyrofi dkk., 2016; Bainamus dkk., 2017; Fauzan \& Arifin, 2017). Hybrid dapat dikatakan juga penggabungan metode dalam pembelajaran (Turgut \& Coban, 2016). Dengan demikian salah satu pengaruh berkurangnya kasus covid - 19 di Indonesia berdampak pada perubahan pembelajaran, yaitu perubahan pembelajaran secara online menjadi pembelajaran secara hybrid.

Di Indonesia hampir seluruh tingkat pendidikan melaksanakan pembelajaran secara hybrid termasuk di perguruan tinggi. Namun demikian setiap perguruan tinggi pasti memiliki kendala dalam pelaksanaan pembelajaran secara hybrid (Buckley dkk., 2021). Beberapa permasalahan yang terjadi adalah pada beberapa mahasiswa yang memiliki kemampuan teknologi rendah dapat menganggu keberhasilan mahasiswa tersebut dalam pembelajaran (Busher dkk., 2015). Selain harus memiliki pengetahuan tentang komputerisasi, pengetahuan dasar mahasiswa mempengaruhi keterlaksanaan pembelajaran secara hybrid (Johnson dkk., 2018). Oleh karena itu pada pembelajaran hybrid perlu dilaksanakan kegiatan keterlibatan antar mahasiswa dalam pembelajaran sesuai dengan kurikulum yang digunakan( Lewis-Kipkulei dkk., 2021). Dengan demikian metode yang tepat sangat diperlukan pada pembelajaran yang dilaksanakan secara hybrid (Kowsher dkk., 2021; Shetu dkk., 2021; Wu dkk., 2019).

Setiap dosen pasti mempunyai metode dalam menyikapi pembelajaran secara hybrid. Salah satu metode yang digunakan oleh dosen saat mengajar pada saat pembelajaran hybrid adalah menggunakan metode ekspositori (Kurniati dkk., 2021). Metode Hybrid Multiple Criteria Decision-Making (HMCDM) dapat membantu dalam pengambilan keputusan (Zavadskas dkk., 2016). Metode Mnemonics dinilai efektif pada pembelajaran secara hybrid pada mata kuliah pengantar statistika (Mocko dkk., 2017). Metode Hybrid-online dinilai layak untuk digunakan dalam perkuliahan (Sentot \& Sujito, 2012). Hybrid Learning Network (HLN) dapat membantu mempercepat proses pembelajaran (Liu \& Xiang, 2017). WhatsApp adalah salah satu media yang dapat membantu mahasiswa dalam pembelajaran (Afnibar \& Fajhriani, 2020; Khasanah dkk., 2021; Mulyono dkk., 2021). Salah satu fitur atau layanan di media WhatsApp adalah layanan Voice Note. Pada saat pembelajaran berlangsung, peneliti menggunakan Voice Note pada WhatsApp, sesekali menggunakan media zoom meeting jika diperlukan, dan menggunakan metode ekspositori untuk mempermudah mahasiswa memahami materi. Penelitian ini bertujuan untuk mengetahui respon mahasiswa pada penggunaan Voice Note pada aplikasi WhatsApp dalam pembelajaran hybrid. Hal ini dilakukan untuk meningkatkan kualitas pembelajaran di program studi pendidikan matematika terutama pada mahasiswa pendidikan matematika di Universitas Wiralodra.

\section{B. Metodologi Penelitian}

Penelitian ini merupakan penelitian kualitatif deskriptif. Populasi penelitian ini adalah mahasiswa Program Studi Pendidikan Matematika. Pengambilan partisipan dilakukan secara purposive sampling. Partisipan pada penelitian ini adalah mahasiswa semester 2 pada tahun akademik 2019/2020 sebanyak 11 orang mahasiswa yang mengikuti matakuliah statistik matematik. Pengumpulan data dilakukan dengan angket. Data yang sudah terkumpul kemudian diolah. Pengolahan data tahap pertama yaitu data dipisahkan pernomor. Setelah data dipisahkan pernomor, data dimasukkan ke Atlas.ti. Setelah data masuk, data tersebut dianalisis perkalimat untuk di reduksi dan dikoding. Selanjutnya data - data yang sudah dikoding di seleksi. Kemudian dilakukan open network untuk mengetahui hasil analisis data. 


\section{Hasil Penelitian dan Pembahasan}

Berikut ditampilkan hasil angket respon mahasiswa terhadap pembelajaran hybrid pada mata kuliah statistik matematik. Pertanyaan pertama: Berapa persenkah pemahaman anda terhadap materi pada matakuliah ini?

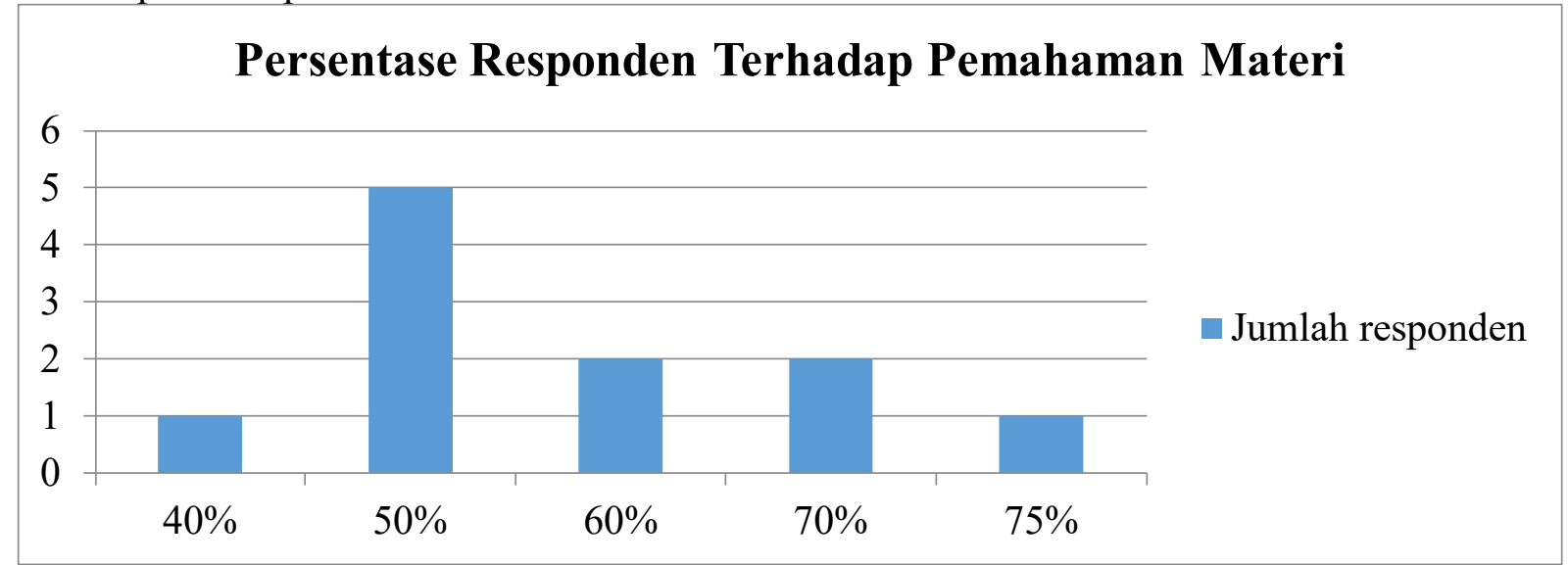

Gambar 1. Diagram Batang Persentase Mahasiswa Terhadap Pemahaman Materi

Gambar 1 merupakan diagram keberhasilan dosen dalam memberikan materi. Persentase pemahaman diukur oleh mahasiswa sendiri berdasarkan pemahaman mahasiswa pada materi materi mata kuliah statistik matematik. Pada gambar di atas, dapat terlihat bahwa sebanyak 5 orang mahasiswa merasa pemahaman terhadap materi yang dipelajari hanya 50 persen. Dengan kata lain, mahasiswa belum paham mengenai materi yang diajarkan oleh dosen. Hal ini diperkuat dengan salah satu mahasiswa hanya mengisi 40 persen. Namun ada juga mahasiswa yang dapat memahami hingga 75 persen. Namun demikian berdasarkan gambar di atas dapat disimpulkan bahwa dosen belum berhasil memfasilitasi mahasiswa dalam mengembangkan pengetahuannya.

Pertanyaan kedua: Bagaimana cara dosen Statistik Matematik memberikan perkuliahan menggunakan media WhatsApp?

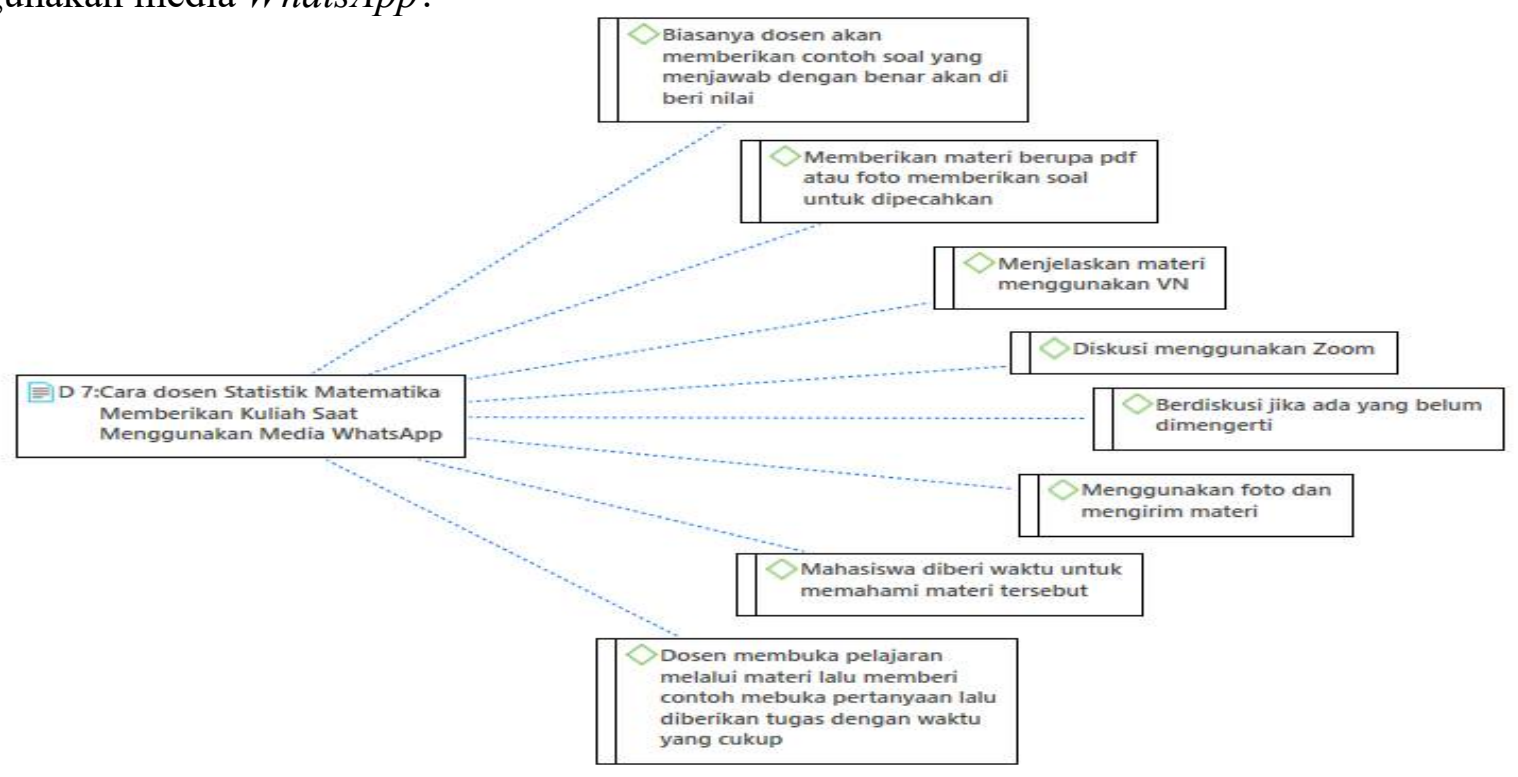

Gambar 2. Respon Mahasiswa terhadap cara dosen memberikan perkuliahan.

Pada Gambar 2 terlihat bahwa dosen menggunakan media WhatsApp dengan fitur voice note. Selain itu dosen juga menggunakan zoom jika mahasiswa meminta dosen untuk menerangkan ulang. Respon mahasiswa yang lain yaitu dosen memberikan materi melalui 
WhatsApp dalam bentuk file atau dalam bentuk foto. Selanjutnya mahasiswa memngungkapkan bahwa dosen memberikan waktu kepada mahasiswa untuk mempelajari materi dan materi yang belum paham boleh bertanya.

Pertaanyaan nomor 3: Apakah metode yang digunakan dapat mengembangkan kemampuan menalar mahasiswa?

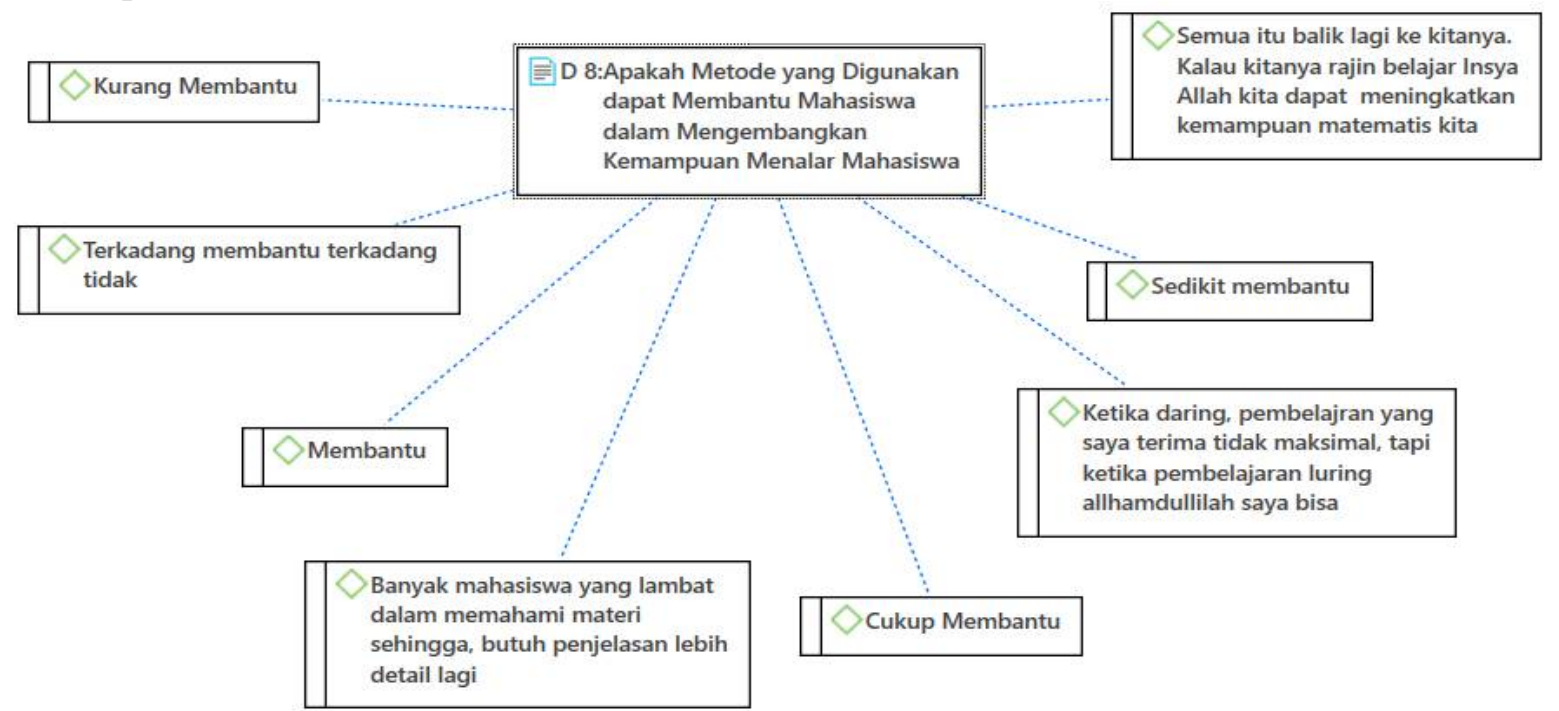

Gambar 3. Respon mahasiswa terhadap metode yang digunakan.

Berdasarkan Gambar 3, metode yang digunakan dosen dalam mengajar, metode pembelajaran yang digunakan dosen yaitu ekspositori dengan bantuan zoom dan voice note pada aplikasi WhatsApp dapat disimpulkan kurang tepat. Hal ini dapat ditunjukkan dengan jawaban mahasiswa yang menyatakan kurang membantu atau sedikit membantu atau cukup membantu. Selain itu pembelajaran secara luring 100\% siharapkan oleh mahasiswa supaya memahami materi yang disampaikan. Respon selanjutnya yaitu mahasiswa meminta penjelasan yang lebih detail lagi terkait dengan materi yang diajarkan oleh dosen.

Pertanyaan nomor 4: Respon Mahasiswa terkait dengan strategi yang diinginkan oleh mahasiswa

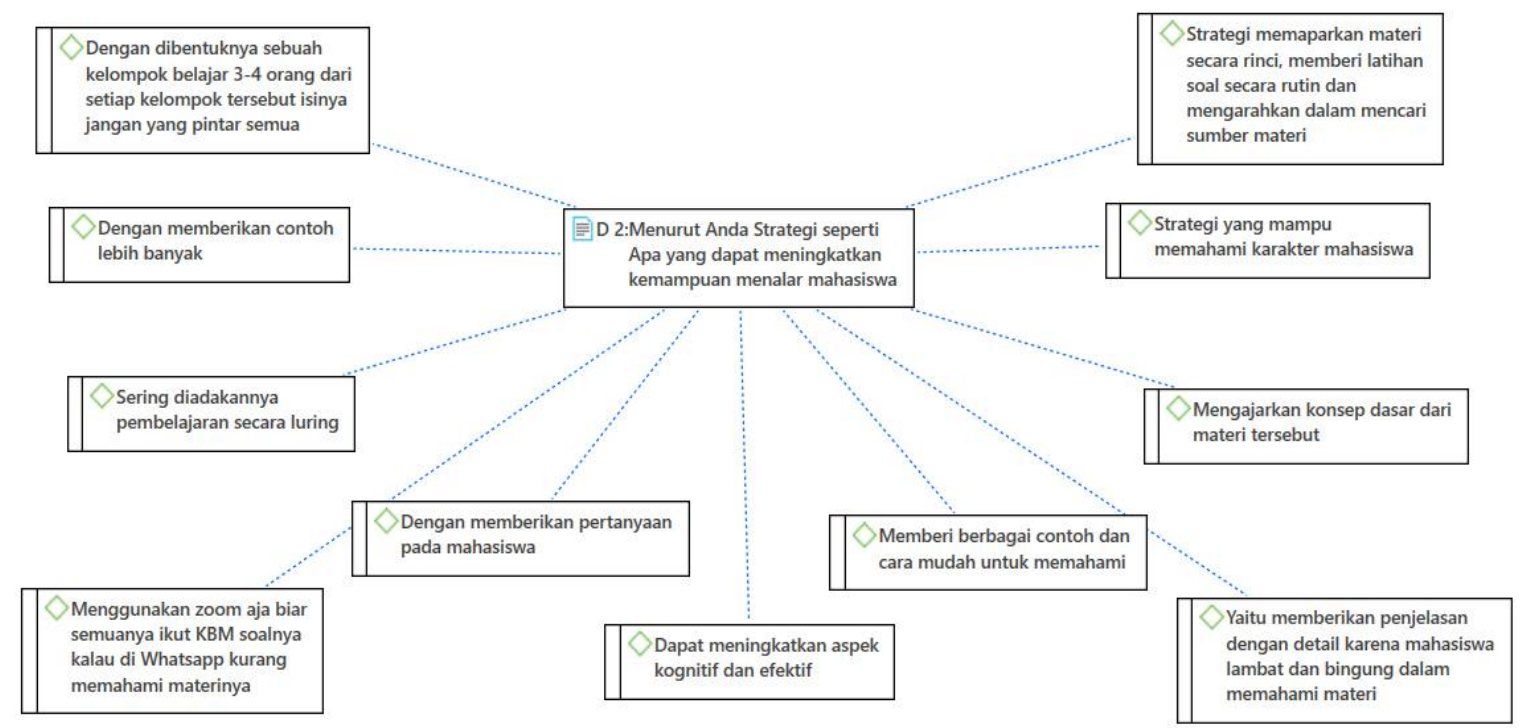

Gambar 4. Respon mahasiswa terkait dengan strategi peningkatan kemampuan menalar

Gambar 4 meninjukkan bahwa respon mahasiswa beraneka ragam. Mahasiswa menginginkan mahasiswa berkelompok dalam pembelajaran, mahasiswa menginginkan adanya 
interaksi antara dosen dan menggunakan zoom pada saat pembelajaran dengan mahasiswa. Selain itu dosen diminta untuk menjelaskan kembali dan pada saat menjelaskan tidak terlalu cepat, serta mahasiswa masih berharap pembelajaran dapat dilakukan secara luring.

Pertanyaan nomor 5: Metode apa yang diinginkan mahasiswa supaya mahasiswa memahami materi?

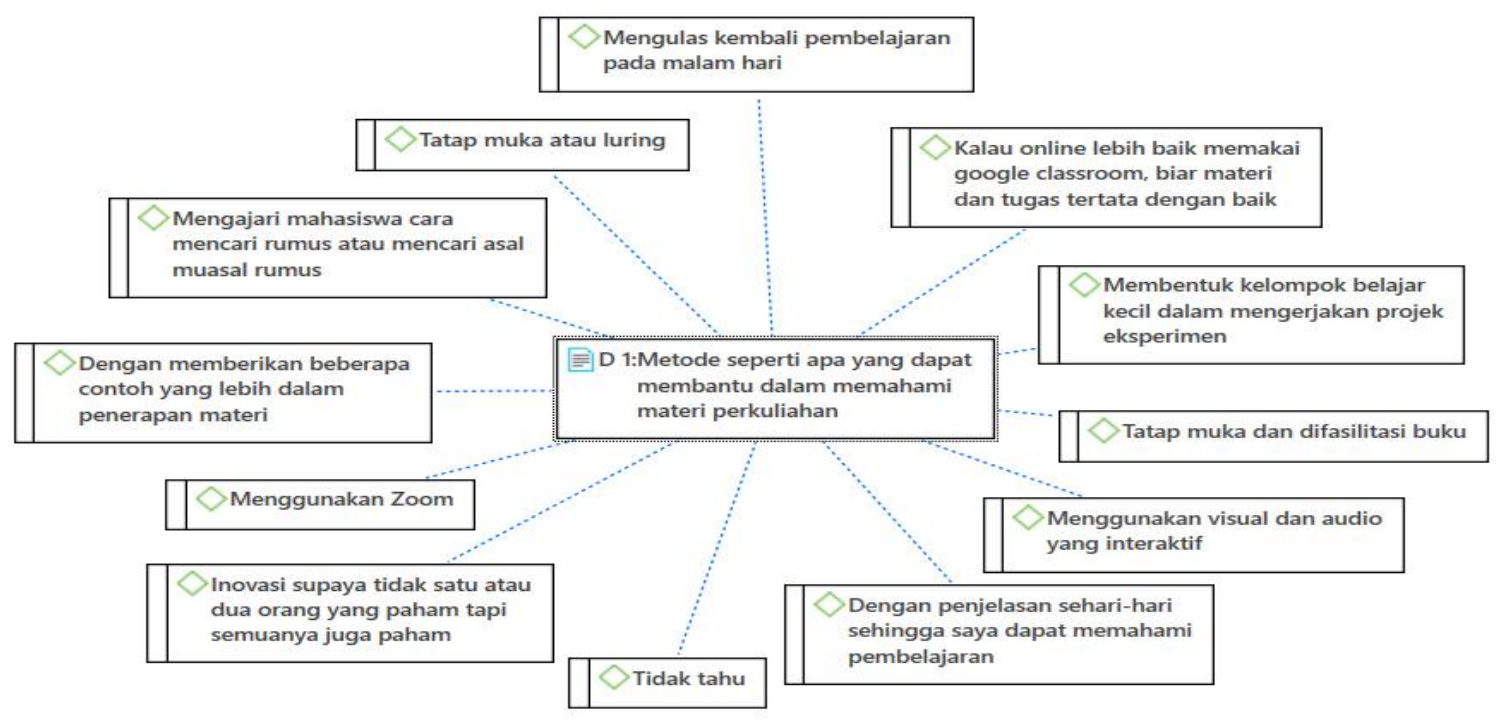

Gambar 5. Respon mahasiswa terhadap Metode yang dapat membantu mahasiswa memahami materi.

Pada gambar 5, mahasiswa menginginkan media yang digunakan diganti dengan google classroom atau zoom saat pembelaajaran daring. Mahasiswa juga berkeinginan dibentuk kelompok sehingga antar mahasiswa dalam satu kelompok dapat saling bekerjasama menyelesaikan proyek. Selain itu mahasiswa memberikan masukan bahwa dosen dapat menggunakan visual dan audio yang interaktif dalam mengajar, serta mahasiswa masih berharap pembelajaran dapat dilakukan secara luring.

Pertanyaan nomor 6: Apa masukan terhadap dosen?

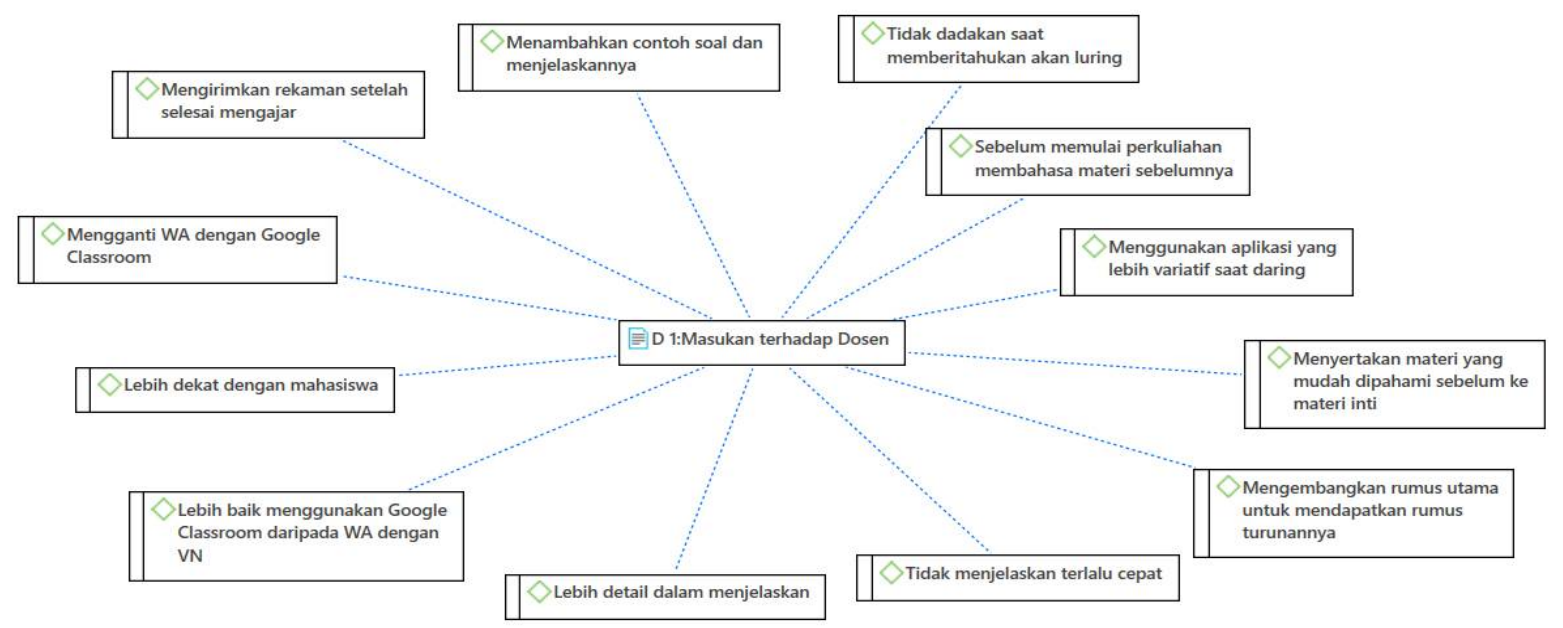

Gambar 6. Masukan kepada Dosen

Pada gambar 6, masukan mahasiswa kepada dosen statistik mathematics. Pada gambar tersebut terlihat bahwa dosen menerangkan terlalu cepat. Diharapkan dosen lebih detail dalam mengajar, mengganti aplikasi yang digunakan, menambahkan contoh dalam latihan dan 
mengganti aplikasi yang digunkan. Serta mahasiswa menginginkan adanya rekaman setelah selesai mengajar.

Berdasarkan tabel dan uraian hasil kuesioner di atas, mahasiswa belum memahami materi dikarenakan belum membantu mahasiswa dalam memahami materi. Hal ini dikarenakan dosen hanya mengirimkan file materi dan pembahasan menggunakan foto dan voice note tanpa menjelaskan secara mendalam mengenai materi yang dipelajari. Selain itu, mahasiswa berharap setelah dosen menjelaskan materi, dosen memberikan video dan ataupun rekaman yang dapat dibagikan kepada mahasiswa. Hal ini akan mempermudah mahasiswa memahami materi karena dapat mengulang - ulang video yang diberikan.

\section{Kesimpulan}

Berdasarkan uraian hasil dan pembahasan di atas, kesimpulan penelitian ini adalah (1) Pada saat mengajar dosen mengirimkan materi berupa file dan foto, selanjutnya dibahas menggunakan WhatsApp melalui Voice Note atau menggunakan Zoom; (2) Metode yang digunakan dosen kurang membantu dalam mengembangkan kemampuan bernalar mahasiswa; (3) Mahasiswa menginginkan pembelajaran luring, pembelajaraan menggunakan Google Classroom, Diskusi, dan lain - lain untuk membantu mahasiswa memahami materi perkuliahan; (4) Menurut mahasiswa, strategi yang dapat meningkatkan kemampuan menalar mahasiswa adalah pembelajaran secara luring, pemberian contoh yang lebih banyak, colaboratif learning, dan lain lain; (5) Saran mahasiswa untuk dosen yaitu dalam mengajar tidak terburu- buru atau terlalu cepat, menggunakan maplikasi sehingga menarik mahasiswa untuk belajar, mengganti aplikasi dalam pembelajaran, dan memberikan rekaman setelah selesai mengajar (6) pembelajaran secara luring sangat diharapkan oleh mahasiswa untuk mendukung pengembangan keterampilan, pengetahuan dan sikap.

\section{DAFTAR PUSTAKA}

Afnibar, A., \& Fajhriani, D. N. (2020). Pemanfaatan WhatsAPP sebagai Media Komunikasi Kegiatan Belajar ( Studi terhadap Mahasiswa UIN Imam Bonjol Padang ). Al-Munir: Jurnal Komunikasi Dan Penyiaran Islam, 11(1), 70-83. https://ejournal.uinib.ac.id/jurnal/index.php/almunir/article/download/1501/1122

Asyrofi, M., Junaedi, I., \& Artikel, I. (2016). Kemampuan Representasi Matematis Ditinjau Dari Multiple Intellingence Pada Pembelajaran Hybrid Learning Berbasis Konstruktivisme. Unnes Journal of Mathematics Education Research, 5(1), 32-39.

Bainamus, P. M., Hartanto, H., \& Abdullah, M. I. (2017). Pengaruh Model Pembelajaran Hibrid Terhadap Kemampuan Komunikasi Matematika Siswa Pada Sekolah Menengah Pertama Negeri 1 Curup Tengah. Jurnal Pendidikan Matematika, 11(2), 16-23. https://doi.org/10.22342/jpm.11.2.3367.

Buckley, K., Stone, S., Farrell, A. M., Glynn, M., Lowney, R., \& Smyth, S. (2021). Learning from student experience: large, higher education classes transitioning online. Irish Educational Studies, 40(2), 399-406. https://doi.org/10.1080/03323315.2021.1916566

Busher, H., James, N., \& Piela, A. (2015). 'I always wanted to do second chance learning': identities and experiences of tutors on Access to Higher Education courses. Research in Post-Compulsory Education, https://doi.org/10.1080/13596748.2015.1030235

20(2), 127-139.

Dryhurst, S., Schneider, C. R., Kerr, J., Freeman, A. L. J., Recchia, G., Bles, A. M. Van Der, Spiegelhalter, D., Dryhurst, S., Schneider, C. R., Kerr, J., Freeman, A. L. J., Recchia, G., 
Bles, A. M. Van Der, Spiegelhalter, D., \& Linden, S. Van Der. (2020). Risk perceptions of COVID-19 around the world. Journal of Risk Research, 0(0), 1-13. https://doi.org/10.1080/13669877.2020.1758193

Evans, C., Howson, C. K., \& Forsythe, A. (2018). Making sense of learning gain in higher education. Higher Education Pedagogies, 3(1), 1-45. https://doi.org/10.1080/23752696.2018.1508360

Fauzan, \& Arifin, F. (2017). Hybrid Learning sebagai Alternatif Model Pembelajaran Fauzan, Fatkhul Hybrid Learning sebagai Alternatif Model Pembelajaran. Seminar Nasional "Profesionalisme Guru Di Era Digital" Menyatakan, 1(1), 247-252.

Ismunandar, D., Primadewi, A., \& Amalia, S. R. (2021). Student Perceptions of Online Learning: Student Opinions and Expectations Persepsi Mahasiswa Terhadap Pembelajaran Secara Online: Pendapat dan Harapan Mahasiswa. Mathline: Jurnal Matematika Dan Pendidikan Matematika, 6(2), 238-251.

Johnson, E., Morwane, R., Dada, S., Pretorius, G., \& Lotriet, M. (2018). Adult Learners' Perspectives on Their Engagement in a Hybrid Learning Postgraduate Programme. Journal of Continuing Higher Education, 66(2), 88-105. https://doi.org/10.1080/07377363.2018.1469071

Khasanah, K., Nasan, E., \& Jus'aini, J. (2021). Efektifitas Media WhatsApp Group Dalam Pembelajaran Daring. Akademika, 10(01), 47-65. https://doi.org/10.34005/akademika.v10i01.1344

Kowsher, M., Tahabilder, A., Islam Sanjid, M. Z., Prottasha, N. J., Uddin, M. S., Hossain, M. A., \& Kader Jilani, M. A. (2021). LSTM-ANN \& BiLSTM-ANN: Hybrid deep learning models for enhanced classification accuracy. Procedia Computer Science, 193, 131-140. https://doi.org/10.1016/j.procs.2021.10.013

Lewis-Kipkulei, P., Singleton, J., Small Singleton, T., \& Davis, K. (2021). Increasing student engagement via a combined roundtable discussion and flipped classroom curriculum model in an OT and special education classroom. Cogent Education, 8(1). https://doi.org/10.1080/2331186X.2021.1911284

Liu, Y., \& Xiang, C. (2017). Hybrid Learning Network: A Novel Architecture for Fast Learning. Procedia Computer Science, 122, 622-628. https://doi.org/10.1016/j.procs.2017.11.415

Mocko, M., Lesser, L. M., Wagler, A. E., \& Francis, W. S. (2017). Assessing effectiveness of mnemonics for tertiary students in a hybrid introductory statistics course. Journal of Statistics Education, 25(1), 2-11. https://doi.org/10.1080/10691898.2017.1294879

Mulyono, H., Suryoputro, G., \& Jamil, S. R. (2021). The application of WhatsApp to support online learning during the COVID-19 pandemic in Indonesia. Heliyon, 7(8), e07853. https://doi.org/10.1016/j.heliyon.2021.e07853

Pratikto, F. R. (2020). Prediksi Akhir Pandemi COVID-19 di Indonesia dengan Simulasi Berbasis Model Pertumbuhan Parametrik. Jurnal Rekayasa Sistem Industri, 9(2), 63-68. https://doi.org/10.26593/jrsi.v9i2.4018.63-68

Sentot, K., \& Sujito. (2012). Pengembangan Model Perkuliahan Hybrid on-Line Untuk. Prosiding Seminar Nasional MIPA Dan Pembelajaran.

Shetu, S. F., Rahman, M. M., Ahmed, A., Mahin, M. F., Akib, M. A. U., \& Saifuzzaman, M. (2021). Impactful e-learning framework: A new hybrid form of education. Current $\begin{array}{llll}\text { Research in Behavioral } & \text { Sciences, April), } & 100038 .\end{array}$ https://doi.org/10.1016/j.crbeha.2021.100038

Turgut, O. E., \& Coban, M. T. (2016). Optimal proton exchange membrane fuel cell modelling based on hybrid Teaching Learning Based Optimization - Differential Evolution algorithm. Ain Shams Engineering Journal, 7(1), 347-360. https://doi.org/10.1016/j.asej.2015.05.003 
Wu, D., Qu, Z. S., Guo, F. J., Zhu, X. L., \& Wan, Q. (2019). Hybrid intelligent deep kernel incremental extreme learning machine based on differential evolution and multiple population grey wolf optimization methods. Automatika, 60(1), 48-57. https://doi.org/10.1080/00051144.2019.1570642

Zavadskas, E. K., Govindan, K., Antucheviciene, J., \& Turskis, Z. (2016). Hybrid multiple criteria decision-making methods: A review of applications for sustainability issues. Economic Research-Ekonomska Istrazivanja , 29(1), 857-887. https://doi.org/10.1080/1331677X.2016.1237302. 